BRAZILIAN JOURNAL OF THERMAL ANALYSIS

http://www.bjta.com.br

\title{
STUDIES ON THE THERMAL BEHAVIOR OF POLYNUCLEAR PALLADIUM(II) COMPOUNDS CONTAINING PYRAZOLATO LIGANDS
}

\author{
Cristiana da Silva ${ }^{1^{*}}$, Antonio E. Mauro ${ }^{2}$, Regina C. G. Frem ${ }^{2}$, Antonio C. Moro ${ }^{2}$, Patricia B. da \\ Silva $^{3}$, Alessandra Stevanato ${ }^{4}$, Eduardo Tonon de Almeida ${ }^{5}$, Adelino V. G. Netto ${ }^{2}$ \\ ${ }^{1}$ UFGD - Univ Federal da Grande Dourados, Faculdade de Ciências Exatas e Tecnologia - Departamento de Química, , \\ P.O. Box 364, 79.804-970, Dourados - MS - Brazil. \\ ${ }^{2}$ UNESP - Univ Estadual Paulista, Instituto de Química de Araraquara - Departamento de Química Geral e Inorgânica, \\ P.O. Box 355, 14801-970, Araraquara-SP-Brazil. \\ ${ }^{3}$ UNESP - Univ Estadual Paulista, Faculdade de Ciências Farmacêuticas, \\ 14800-903, Araraquara-SP-Brazil. \\ ${ }^{4}$ UTFPR - Univ Tecnológica Federal do Paraná - Departamento de Química, \\ P.O. Box 135, 86036-370, Londrina-PR-Brazil. \\ ${ }^{5}$ UNIFAL -Univ Federal de Alfenas - Instituto de Química, \\ 37130-000, Alfenas - MG-Brazil. \\ *cristiana_silva28@yahoo.com.br
}

\section{Received: \\ Published online: $<$ bjta $>$}

Keywords: palladium(II) compounds azide pyrazole polynuclear compounds Thermal stability

\begin{abstract}
The synthesis, spectroscopic characterization and thermal behavior of the pyrazolate-bridged palladium complexes $\left[\mathrm{Pd}_{3}\left(\mu-\mathrm{N}_{3}\right)(\mu-\mathrm{Pz})_{5}\right]_{\mathrm{n}}(1),\left[\mathrm{Pd}_{3}(\mu-\right.$ $\left.\left.\mathrm{N}_{3}\right)(\mu-\mathrm{mPz})_{5}\right]_{\mathrm{n}}(2),\left[\mathrm{Pd}_{3}\left(\mu-\mathrm{N}_{3}\right)(\mu-\mathrm{IPz})_{5}\right]_{\mathrm{n}}(3),\left[\mathrm{Pd}_{6}\left(\mu-\mathrm{N}_{3}\right)_{2}(\mu-\mathrm{Pz})_{5}(\mu-\mathrm{mPz})_{5}\right]_{\mathrm{n}}$ (4), $\left[\mathrm{Pd}_{6}\left(\mu-\mathrm{N}_{3}\right)_{2}(\mu-\mathrm{Pz})_{5}(\mu-\mathrm{dmPz})_{5}\right]_{\mathrm{n}}(5)$ and $\left[\mathrm{Pd}_{6}\left(\mu-\mathrm{N}_{3}\right)_{2}(\mu-\mathrm{Pz})_{5}(\mu-\mathrm{IPz})_{5}\right]_{\mathrm{n}}$ (6) \{pyrazolate $\left(\mathrm{Pz}^{-}\right)$, 4-methylpyrazolate $\left(\mathrm{mPz}^{-}\right)$, 3,5-dimethylpyrazolate $\left(\mathrm{dmPz}^{-}\right)$, 4-iodopyrazolate $\left.\left(\mathrm{IPz}^{-}\right)\right\}$have been described in this work. The thermal decomposition of the compounds occurs in four or five stages and the final decomposition residues were identified as metallic palladium using X-ray powder diffraction method. TG studies showed that the introduction of substituted pyrazolato groups in the composition of the polynuclear compounds affect significantly their thermal stability. It can be concluded that the presence of pyrazolato ligands containing methyl or iodine groups at the 4 position has a crucial effect on the thermal stability of the polynuclear compounds described in this work.
\end{abstract}

\section{Introduction}

The design of one-, two- or threedimensional metallosupramolecular species with fascinating topologies and desired functions [1], such as optical [2], porous [3], magnetic [4-5] and electrochemical [6] molecular materials, represents one of the most exciting and challenging research topics in current chemistry [7-8]. Among the $\mathrm{N}$-donor bridging ligands employed in the self-assembly 
reactions [9], pyrazolato groups have emerged as promising $60^{\circ}$ angular building blocks [10]. Homoleptic pyrazolate metallosupramolecules exhibit a rich structural diversity (e.g. triangles, tetramers, polynuclear compounds) which is dependent on the reaction conditions, the side chains at the pyrazolate ligand and the geometry at the metal centres [11-13]. Similarly to their binary counterparts, heteroleptic pyrazolate derivatives are wellknown to possess also unusual structures and peculiar properties. For instance, the compound $[\mathrm{Cu}(\mu-\mathrm{dmPz})(\mu-\mathrm{OH})]_{8} \quad[14], \quad$ a discrete octameric molecule with a cyclic planar system of copper(II) atoms bridged by $\mathrm{OH}$ and 3,5dimethylpyrazolato (dmpz) ligands, acts as catalyst in the oxidation reactions of a variety of organic substrates. Raptiset al. have reported that metallacycles complexes of general formulae $\left[\left\{c i s-\mathrm{Cu}^{\mathrm{II}}(\mu-\mathrm{OH})(\mu-\mathrm{pz})\right\}_{\mathrm{n}}\right](\mathrm{n}=6,8$, 9, 12 and 14) are self-assembled with their lipophilic pyrazolates $(\mathrm{Pz})$ oriented towards the outer surface and their hydrophilic $\mathrm{OH}$ groups towards an encapsulated anion at the inner cavity of the assembly [15]. These copper metallacrowns possess the ability to bind anions through the cooperative $\mathrm{H}$ bonding to all bridging $\mathrm{OH}$ groups due to their inward oriented oxygen electron lone pairs.

Some years ago, we have described the spontaneous formation of polynuclear compounds from the reaction among $\left[\mathrm{PdCl}_{2}\left(\mathrm{MeCN}_{2}\right]\right.$, neutral pyrazoles $(\mathrm{HPz})$ and azide ions [16-17]. These amorphous compounds were characterized as $\left[\mathrm{Pd}_{3}(\mu-\right.$ $\left.\left.\mathrm{N}_{3}\right)(\mu-\mathrm{Pz})_{5}\right]_{\mathrm{n}} \quad(\mathbf{1}), \quad\left[\mathrm{Pd}_{3}\left(\mu-\mathrm{N}_{3}\right)(\mu-\mathrm{mPz})_{5}\right]_{\mathrm{n}} \quad$ (2), $\left[\mathrm{Pd}_{3}\left(\mu-\mathrm{N}_{3}\right)(\mu-\mathrm{IPz})_{5}\right]_{\mathrm{n}}(\mathbf{3}),\left[\mathrm{Pd}_{6}\left(\mu-\mathrm{N}_{3}\right)_{2}(\mu-\mathrm{Pz})_{5}(\mu-\right.$ $\left.\mathrm{mPz})_{5}\right]_{\mathrm{n}}(4),\left[\mathrm{Pd}_{6}\left(\mu-\mathrm{N}_{3}\right)_{2}(\mu-\mathrm{Pz})_{5}(\mu-\mathrm{dmPz})_{5}\right]_{\mathrm{n}}(\mathbf{5})$ and $\quad\left[\mathrm{Pd}_{6}\left(\mu-\mathrm{N}_{3}\right)_{2}(\mu-\mathrm{Pz})_{5}(\mu-\mathrm{IPz})_{5}\right]_{\mathrm{n}}$ \{pyrazolate $\left(\mathrm{Pz}^{-}\right)$, 4-methylpyrazolate $\left(\mathrm{mPz}^{-}\right)$, 3,5-dimethylpyrazolate $\quad\left(\mathrm{dmPz}^{-}\right), \quad 4-$ iodopyrazolate $\left.\left(\mathrm{IPz}^{-}\right)\right\}$according to the results obtained from elemental analysis, vapor phase osmometry, infrared (IR), ultraviolet-visible (UV-Vis) and nuclear magnetic resonance (NMR) spectroscopies. An interesting property of these polynuclear compounds is their good ability to form thin films by spin coating using chloroform solutions, which could be useful for new uses of such species. Particularly, metal azido complexes are of technological interest since they can be employed as forerunners for the photolithography of metallic films [18]. To achieve such goal, it is desirable that the photolysis of the azido compounds gives rise to thermally unstable intermediates which further decompose into the metallic form. In this sense, the thermal stability of azido complexes is an important parameter to be investigated. As a part of our ongoing studies on the structure and properties of palladium(II) compounds [19-28], we describe herein an investigation of the thermal behavior of the polynuclear complexes 1-6 by means of thermogravimetry (TG) and Differential Thermal Analysis (DTA), as depicted in Figure 1-2. 


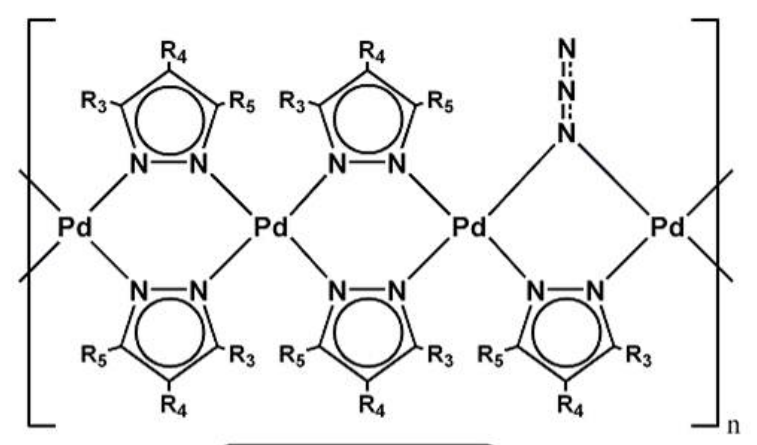

$$
\begin{array}{|rccc} 
& \mathbf{R}_{\mathbf{3}} & \mathbf{R}_{\mathbf{4}} & \mathbf{R}_{\mathbf{5}} \\
\mathbf{P z} & \mathrm{H} & \mathrm{H} & \mathrm{H} \\
\mathbf{m P z} & \mathrm{H} & \mathrm{CH}_{3} & \mathrm{H} \\
\mathbf{I P z} & \mathrm{H} & \mathrm{I} & \mathrm{H} \\
\hline
\end{array}
$$

Figure 1. Proposed structure of the compounds of the type $\left[\mathrm{Pd}_{3}\left(\mu-\mathrm{N}_{3}\right)(\mu-\mathrm{L})_{5}\right]_{\mathrm{n}}\left\{\mathrm{L}=\mathrm{Pz}^{-}(\mathbf{1}), \mathrm{mPz}^{-}(\mathbf{2}), \mathrm{IPz}(\mathbf{3})\right\}$

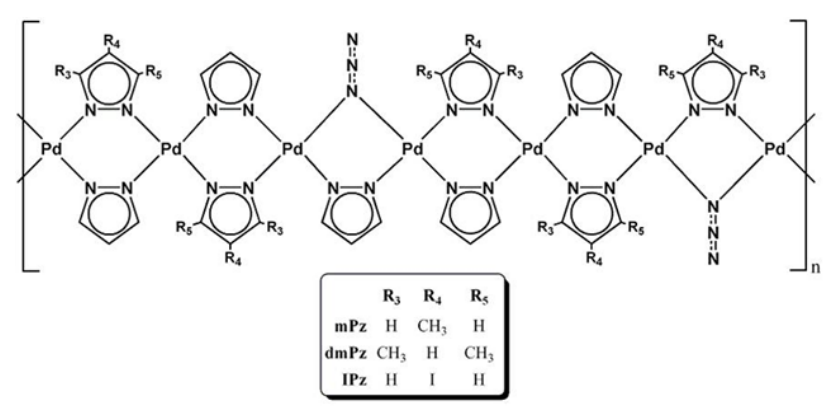

Figure 2. Proposed structure of the compounds of the type $\left[\mathrm{Pd}_{6}\left(\mu-\mathrm{N}_{3}\right)_{2}(\mu-\mathrm{Pz})_{5}(\mu-\mathrm{L})_{5}\right]_{\mathrm{n}}\left\{\mathrm{L}=\mathrm{mPz}^{-}(\mathbf{4}), \mathrm{dmPz}^{-}(\mathbf{5}), \operatorname{IPz}(\mathbf{6})\right\}$

\section{Materials and methods}

\section{General comments}

All the synthesis have been carried out at room temperature. All reagents were obtained from commercial suppliers. The starting complex $\left[\mathrm{PdCl}_{2}\left(\mathrm{CH}_{3} \mathrm{CN}\right)_{2}\right]$ was prepared as previously described [29].

Synthesis
Synthesis of the complexes 1-3 [16-17]

Briefly, to a deep orange solution of $\left[\mathrm{PdCl}_{2}\left(\mathrm{CH}_{3} \mathrm{CN}\right)_{2}\right](0.39 \mathrm{mmol})$ in $10 \mathrm{~mL}$ of $\mathrm{MeOH}$, the appropriate pyrazolyl ligand $(0.81$ mmol) dissolved in $2 \mathrm{~mL}$ of methanol was added dropwise. After stirring the resulting mixture for $5 \mathrm{~min}, \mathrm{NaN}_{3}(0.81 \mathrm{mmol})$ dissolved in $2 \mathrm{~mL}$ of water was added dropwise yielding a yellow suspension, which was filtered off and the obtained solid was washed with methanol and dried under vacuum. Yield $75 \%$. Anal. Calcd. For $1\left(\mathrm{C}_{165} \mathrm{H}_{167} \mathrm{~N}_{143} \mathrm{Pd}_{32}\right) \%$ : C, 26.2; N 26.5; H, 2.2. Found: C, 25.9; N 26.2; H, 2.2, for $2\left(\mathrm{C}_{220} \mathrm{H}_{277} \mathrm{~N}_{143} \mathrm{Pd}_{32}\right) \%$ : C, 31.7; N 23.4; $\mathrm{H}$, 4.0. Found: $\mathrm{C}, 31.9 ; \mathrm{N} 23.4 ; \mathrm{H}, 4.1$, and 3 $\left(\mathrm{C}_{165} \mathrm{H}_{112} \mathrm{~N}_{143} \mathrm{I}_{55} \mathrm{Pd}_{32}\right) \%$ : C, 13.7; N 13.6; H, 0.8. Found: C, 13.5; N 13.5; H, 0.9 .

Synthesis of the complexes 4-6 [16]

Briefly, pyrazole $(0.43 \mathrm{mmol})$ and corresponding substituted pyrazolyl ligand (0.43 mmol), dissolved in $2 \mathrm{~mL}$ of methanol, were added dropwise to a deep orange solution of $\left[\mathrm{PdCl}_{2}\left(\mathrm{CH}_{3} \mathrm{CN}\right)_{2}\right](0.39 \mathrm{mmol})$ in $10 \mathrm{~mL}$ of $\mathrm{MeOH}$. After stirring the resulting the resulting mixture for $5 \mathrm{~min}, \mathrm{NaN}_{3} \quad(0.81 \mathrm{mmol})$ dissolved in $2 \mathrm{~mL}$ of water was added affording a yellow suspension, which was filtered off and the obtained solid was washed with methanol and dried under vacuum. Yield $70 \%$. Anal. Calc. For $4\left(\mathrm{C}_{367} \mathrm{H}_{421} \mathrm{~N}_{273} \mathrm{Pd}_{62}\right) \%$ : C, 28.9; N 
25.1; H, 2.8. Found: C, 29.3; N 24.9; H, 3.0, for $5\left(\mathrm{C}_{419} \mathrm{H}_{525} \mathrm{~N}_{273} \mathrm{Pd}_{62}\right) \%$ : C, 31.5; $\mathrm{N} 23.6 ; \mathrm{H}$, 3.6. Found: $\mathrm{C}, 31.6 ; \mathrm{N} 23.9 ; \mathrm{H}, 3.5$, and $\mathbf{6}$ $\left(\mathrm{C}_{315} \mathrm{H}_{262} \mathrm{~N}_{273} \mathrm{I}_{52} \mathrm{Pd}_{62}\right) \%$ : C, 18.0; N 18.1; H, 1.3. Found: C, 17.9; N 17.8; H, 1.3.

\section{Instrumentation}

Elemental analysis of carbon, nitrogen and hydrogen were performed on a microanalyser elemental analyser $\mathrm{CHN}$, model 1112 FLASH EA. Infrared spectra were recorded in $\mathrm{KBr}$ pellets on a Nicolet model SX-FT-Impact 400 spectrophotometer in the 4000-400 $\mathrm{cm}^{-1}$ spectral range. Melting points were determined on a MAPFQ apparatus. Thermal analyses (TG) and differential thermal analysis (DTA) were carried out using a TA Instruments model SDQ 600, under flow of dry synthetic air $\left(50 \mathrm{~mL} \mathrm{~min}^{-1}\right)$, temperature up to $900{ }^{\circ} \mathrm{C}$ and at heating rate of $20^{\circ} \mathrm{C} \mathrm{min}^{-1}$ in $\alpha$ alumina sample holders. The reference substance was pure $\alpha$-alumina in DTA measurements. X-ray powder diffraction patterns were measured on a Siemens D-5000 $\mathrm{X}$-ray diffractometer using $\mathrm{CuK}_{\alpha}$ radiation $(\lambda=$ $1.541 \AA$ ) and setting of $34 \mathrm{kV}$ and $20 \mathrm{~mA}$. The peaks were identified using ICDD bases [3031].

\section{Results and discussion}

The results of the elemental analysis agree well with the formulation $\left[\operatorname{Pd}_{3}\left(\mu-\mathrm{N}_{3}\right)(\mu\right.$ $\left.\mathrm{Pz})_{5}\right]_{\mathrm{n}}$ (1), $\left[\mathrm{Pd}_{3}\left(\mu-\mathrm{N}_{3}\right)(\mu-\mathrm{mPz})_{5}\right]_{\mathrm{n}} \quad(2),\left[\mathrm{Pd}_{3}(\mu-\right.$ $\left.\left.\mathrm{N}_{3}\right)(\mu-\mathrm{IPz})_{5}\right]_{\mathrm{n}}(\mathbf{3}),\left[\mathrm{Pd}_{6}\left(\mu-\mathrm{N}_{3}\right)_{2}(\mu-\mathrm{Pz})_{5}(\mu-\mathrm{mPz})_{5}\right]_{\mathrm{n}}$ (4), $\quad\left[\mathrm{Pd}_{6}\left(\mu-\mathrm{N}_{3}\right)_{2}(\mu-\mathrm{Pz})_{5}(\mu-\mathrm{dmPz})_{5}\right]_{\mathrm{n}} \quad$ (5) and $\left[\mathrm{Pd}_{6}\left(\mu-\mathrm{N}_{3}\right)_{2}(\mu-\mathrm{Pz})_{5}(\mu-\mathrm{IPz})_{5}\right]_{\mathrm{n}} \quad$ (6) $\quad[16] . \quad$ IR evidences clearly evidenced the exobidentate nature of pyrazolate ligands by the absence of the $v_{\mathrm{NH}}$ band at ca. $3400-3200 \mathrm{~cm}^{-1}$ as well as by the shift of the $v_{\text {ring }}$ absorption to lower frequency (1491-1530 $\left.\mathrm{cm}^{-1}\right)$ when compared with that one of the free ligands (1533-1596 $\left.\mathrm{cm}^{-1}\right)$. A strong $v_{\mathrm{s}} \mathrm{N}_{3}$ band appeared in the 2081-2087 $\mathrm{cm}^{-1}$ region in all IR spectra being therefore consistent of bridging azide [16].

\section{Thermal behavior studies}

The TG and DTA curves obtained for the compounds 1-6 are shown in Figure 3 and 4 and the results of the thermal investigations are listed in Table 1.



Figure 3. TG and DTA curves of the complexes $\left[\operatorname{Pd}_{3}\left(\mu-\mathrm{N}_{3}\right)(\mu-\right.$ $\left.\mathrm{L})_{5}\right]_{\mathrm{n}}\left\{\mathrm{L}=\mathrm{Pz}^{-}(\mathbf{1}), \mathrm{mPz}^{-}(\mathbf{2}), \mathrm{IPz}(3)\right\}$. 


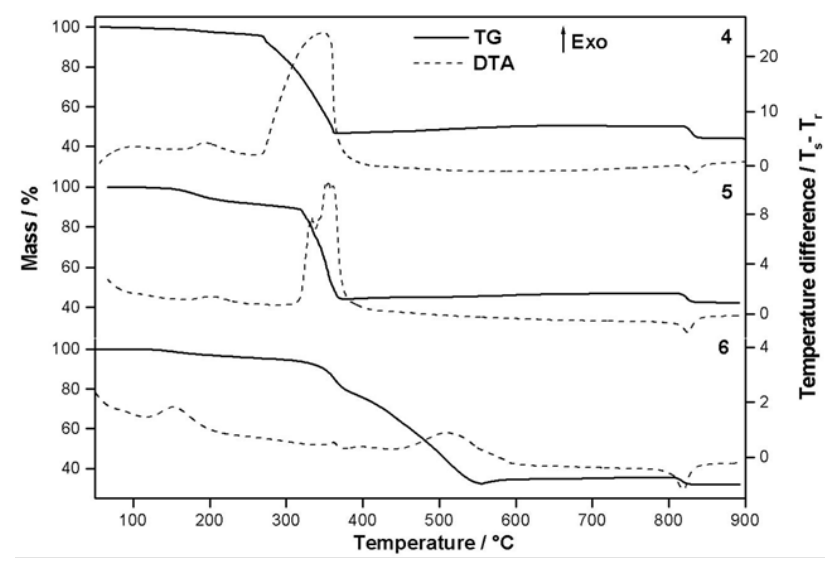

Figure 4. TG and DTA curves of the complexes $\left[\operatorname{Pd}_{6}\left(\mu-\mathrm{N}_{3}\right)_{2}(\mu-\right.$ $\left.\mathrm{Pz})_{5}(\mu-\mathrm{L})_{5}\right]_{\mathrm{n}}\left\{\mathrm{L}=\mathrm{mPz}^{-}(\mathbf{4}), \mathrm{dmPz}^{-}(\mathbf{5}), \mathrm{IPz}(\mathbf{6})\right\}$

Table 1 Thermal analysis data for the compounds $\left[\operatorname{Pd}_{3}(\mu-\right.$ $\left.\left.\mathrm{N}_{3}\right)(\mu-\mathrm{Pz})_{5}\right]_{\mathrm{n}} \quad(1), \quad\left[\mathrm{Pd}_{3}\left(\mu-\mathrm{N}_{3}\right)(\mu-\mathrm{mPz})_{5}\right]_{\mathrm{n}} \quad(2), \quad\left[\mathrm{Pd}_{3}\left(\mu-\mathrm{N}_{3}\right)(\mu-\right.$ IPz) 5$]_{\mathrm{n}}(3),\left[\mathrm{Pd}_{6}\left(\mu-\mathrm{N}_{3}\right)_{2}(\mu-\mathrm{Pz})_{5}(\mu-\mathrm{mPz})_{5}\right]_{\mathrm{n}}(4),\left[\mathrm{Pd}_{6}\left(\mu-\mathrm{N}_{3}\right)_{2}(\mu-\right.$ $\mathrm{Pz})_{5}\left(\mu-\mathrm{dmPz}_{5}\right]_{\mathrm{n}}(\mathbf{5})$ and $\left[\mathrm{Pd}_{6}\left(\mu-\mathrm{N}_{3}\right)_{2}(\mu-\mathrm{Pz})_{5}(\mu-\mathrm{IPz})_{5}\right]_{\mathrm{n}}(\mathbf{6})$

\begin{tabular}{|c|c|c|c|c|c|}
\hline \multirow{2}{*}{ Complex } & \multirow{2}{*}{ Step } & \multirow{2}{*}{$\Delta \mathrm{T} /{ }^{\circ} \mathrm{C}$} & \multirow{2}{*}{$\Delta \mathrm{m} / \%$} & \multicolumn{2}{|c|}{ DTA peak $/{ }^{\circ} \mathrm{C}$} \\
\hline & & & & endo & exo \\
\hline \multirow{4}{*}{1} & 1 & $70-248$ & -5.15 & & 161 \\
\hline & 2 & $248-297$ & -44.68 & & 293 \\
\hline & 3 & $97-809$ & +2.52 & & \\
\hline & $\begin{array}{c}4 \\
\text { residue }\end{array}$ & $809-854$ & $\begin{array}{r}-6.49 \\
46.20\end{array}$ & 824 & \\
\hline \multirow{5}{*}{2} & 1 & $143-276$ & -5.95 & & 173 \\
\hline & 2 & $276-397$ & -49.72 & & 295,335 \\
\hline & 3 & 397-800 & +4.02 & & \\
\hline & 4 & $800-865$ & -5.67 & 822 & \\
\hline & residue & & 42.69 & & \\
\hline \multirow{5}{*}{3} & 1 & $147-310$ & -4.93 & & 160 \\
\hline & 2 & 310-395 & -22.05 & & 378 \\
\hline & 3 & $395-566$ & -48.35 & & 513 \\
\hline & 4 & $566-808$ & +1.08 & & \\
\hline & $\begin{array}{c}5 \\
\text { residue }\end{array}$ & $808-860$ & $\begin{array}{r}-1.34 \\
24.41\end{array}$ & 814 & \\
\hline \multirow{6}{*}{4} & 1 & $148-245$ & -4.29 & & 174 \\
\hline & 2 & $245-354$ & -49.02 & & 331 \\
\hline & 3 & $354-802$ & +3.42 & & \\
\hline & 4 & $802-866$ & -6.02 & 831 & \\
\hline & residue & & 44.11 & & \\
\hline & 1 & $105-216$ & -7.71 & & 181 \\
\hline \multirow[t]{4}{*}{5} & 2 & $216-367$ & -48.18 & & 315,339 \\
\hline & 3 & $367-805$ & +2.87 & & \\
\hline & 4 & $805-867$ & -4.60 & 831 & \\
\hline & residue & & 42.38 & & \\
\hline \multirow{6}{*}{6} & 1 & $126-230$ & -3.89 & & 152 \\
\hline & 2 & $230-384$ & -17.82 & & \\
\hline & 3 & $384-583$ & -44.07 & & 510 \\
\hline & 4 & $583-805$ & +1.16 & & \\
\hline & 5 & $805-860$ & -3.39 & 818 & \\
\hline & residue & & 31.99 & & \\
\hline
\end{tabular}

The thermal degradation pattern of 1 consists of a gradual mass loss of $5.15 \%$ over the temperature range $70-248{ }^{\circ} \mathrm{C}$. This first decomposition stage is ascribed to the elimination of small molecules that are released from the decomposition of the chain termination, which is accompanied by an exothermic signal of low intensity at $161{ }^{\circ} \mathrm{C}$. Therefore, it seems reasonable to consider that the polynuclear backbone of $\mathbf{1}$ is thermally stable until $248{ }^{\circ} \mathrm{C}$. A further heating to $297{ }^{\circ} \mathrm{C}$ resulted in an abrupt weight loss of $44.68 \%$ attributed to the oxidation of the main polynuclear chain, being accompanied by a very intense exothermic signal at $293{ }^{\circ} \mathrm{C}$. A progressive mass gain of $2.52 \%$ up to $809{ }^{\circ} \mathrm{C}$ is ascribed to the formation of additional $\mathrm{Pd}$ which is further decomposed into Pd (Calcd. $45.83 \%$, Found $46.20 \%$ ) at $854{ }^{\circ} \mathrm{C}$. This event is associated with the endothermic peak at 824 ${ }^{\circ} \mathrm{C}$ which is characteristic of the decomposition of $\mathrm{PdO}$ to $\mathrm{Pd}[30-31]$.

A small mass loss of $5.95 \%$ upon heating of the sample in the range of 143-276 ${ }^{\circ} \mathrm{C}$ is observed in the TG-DTA curves of compound 2. Similarly to the thermal behavior of $\mathbf{1}$, the main chain of $\mathbf{2}$ remains stable until $276^{\circ} \mathrm{C}$. A further increase in the temperature to $397{ }^{\circ} \mathrm{C}$ resulted in two overlapped steps with a total mass loss of $49.72 \%$ which are related to two intense exothermic events at 295 and 335 ${ }^{\circ} \mathrm{C}$. 
Compound 3 decomposed more slowly than 1 and 2. The first step $\left(147-310{ }^{\circ} \mathrm{C}\right)$ is characterized by a mass loss of $4.93 \%$ accompanied by an exothermic signal at 160 ${ }^{\circ} \mathrm{C}$, probably associated with the partial release of iodine at the 4 position on the pyrazolyl ring [10]. Afterwards, two consecutive mass losses of $22.05 \%$ and $48.35 \%$ are related to the thermal breakdown of the main chain, leading to a mixture of $\mathrm{Pd}$ and $\mathrm{PdO}$. Two exothermic signals at $378{ }^{\circ} \mathrm{C}$ and $513{ }^{\circ} \mathrm{C}$ are involved in this oxidation process.

The thermal decomposition pattern of compound $\mathbf{4}$ is similar to that observed for $\mathbf{1}$. The first stage $\left(148-245^{\circ} \mathrm{C}\right)$ is characterized by a progressive and slow mass loss of $4.29 \%$ associated with an exothermic event at $174{ }^{\circ} \mathrm{C}$. The breakdown of the polynuclear backbone of 4 is detected with a further increase of temperature to $354{ }^{\circ} \mathrm{C}$, resulting in a considerable mass loss of $49.02 \%$ accompanied by a broad exothermic event centered at $331{ }^{\circ} \mathrm{C}$, affording a mixture of $\mathrm{Pd}$ and PdO.

Compound 5 started to degrade at $105{ }^{\circ} \mathrm{C}$, from which is noticed a mass loss of $7.71 \%$ accompanied by a weak exothermic signal at $181{ }^{\circ} \mathrm{C}$. A mass loss of $48.18 \%$ is observed in the range of $216-367{ }^{\circ} \mathrm{C}$ step related to the breakdown of the main chain. This abrupt mass loss is accompanied by two exothermic signals at $315^{\circ} \mathrm{C}$ and $339{ }^{\circ} \mathrm{C}$, leading to a mixture of
$\mathrm{PdO}$ and $\mathrm{Pd}^{0}$. A slight and progressive mass gain of $2.87 \%$ occurred up to $805^{\circ} \mathrm{C}$ which is ascribed to the oxidation of $\mathrm{Pd}^{0}$ to $\mathrm{PdO}$. The decomposition of $\mathrm{PdO}$ to $\mathrm{Pd}^{0}$ is observed in the last mass loss (4.60\%) between 805 and 867 ${ }^{\circ} \mathrm{C}$, which is accompanied by endothermic peak at $831{ }^{\circ} \mathrm{C}$.

The TG-DTA curves for compound $\mathbf{6}$ are similar to those obtained for 3. The first step $\left(126-230{ }^{\circ} \mathrm{C}\right)$ is characterized by a slow and progressive mass loss of $3.89 \%$, accompanied by an exothermic signal at $152{ }^{\circ} \mathrm{C}$. A mass loss of $17.82 \%$ is noticed as the temperature rises to $384^{\circ} \mathrm{C}$, followed by a substantial mass loss of $44.07 \%$ at $583{ }^{\circ} \mathrm{C}$ attributed to the breakdown of the polynuclear structure, affording a mixture of $\mathrm{Pd}^{0}$ and $\mathrm{PdO}$.

From the inspection of TG curves some interesting trends can be observed. The TG curves showed that the introduction of different ligands pyrazole in the backbone of the polynuclear compounds causes significant effects on their thermal stability. Compounds $\mathbf{1}$, 2 and 4 gradually lose $c a .5$ wt. \% of their total mass as the temperature rises from 70, 143 and $148{ }^{\circ} \mathrm{C}$ to 248,276 and $245^{\circ} \mathrm{C}$, respectively. It seems probable that this first decomposition step is attributed to the elimination of small molecules that are released from the degradation of the chain ends. The appearance of an exothermic event in the range of 161-174 ${ }^{\circ} \mathrm{C}$ in the DTA curves of $\mathbf{1 , 2}$ and $\mathbf{4}$ agrees well 
with this proposition. A further increase of the above mentioned temperatures, the main chain of 1, 2 and $\mathbf{4}$ decomposes quickly, losing about 45-49 wt. \% at 297, 397 and $354{ }^{\circ} \mathrm{C}$, respectively. Consequently, it can be concluded that the number of pyrazolato ligands containing methyl groups at the 4 position has a crucial effect on its thermal stability. Taking into account the initial temperature of decomposition, as the number of 4methylpyrazolato groups increases in the polynuclear backbone, the thermal stability increases according to the sequence: $\mathbf{2} \approx \mathbf{4}>\mathbf{1}$. The presence of 4-iodopyrazolate in the polynuclear chain (ex. 3 and 6) also increases the thermal stability when compared to $\mathbf{1}$, following the trend: $\mathbf{3}>\mathbf{6}>\mathbf{1}$. Compound $\mathbf{5}$, which contains pyrazolate and 3,5dimethylpyrazolate groups in its composition, loses $\sim 8$ wt. $\%$ of their total mass as the temperature rises from 105 to $216^{\circ} \mathrm{C}$. From these results it is noticed that $\mathbf{5}$ presents higher thermal stability than the compound $\mathbf{1}$, but is less thermally stable than the 4-methyl and 4iodopyrazolate-based derivatives $\mathbf{2 , 3 , 4}$, and $\mathbf{6}$.

\section{Conclusions}

The synthesis and thermal behavior studies on the polynuclear compounds $\left[\operatorname{Pd}_{3}(\mu-\right.$ $\left.\left.\mathrm{N}_{3}\right)(\mu-\mathrm{Pz})_{5}\right]_{\mathrm{n}} \quad(\mathbf{1}), \quad\left[\mathrm{Pd}_{3}\left(\mu-\mathrm{N}_{3}\right)(\mu-\mathrm{mPz})_{5}\right]_{\mathrm{n}} \quad$ (2), $\left[\mathrm{Pd}_{3}\left(\mu-\mathrm{N}_{3}\right)(\mu-\mathrm{IPz})_{5}\right]_{\mathrm{n}}(\mathbf{3}),\left[\operatorname{Pd}_{6}\left(\mu-\mathrm{N}_{3}\right)_{2}(\mu-\mathrm{Pz})_{5}(\mu-\right.$ $\left.\mathrm{mPz})_{5}\right]_{\mathrm{n}}(4),\left[\mathrm{Pd}_{6}\left(\mu-\mathrm{N}_{3}\right)_{2}(\mu-\mathrm{Pz})_{5}(\mu-\mathrm{dmPz})_{5}\right]_{\mathrm{n}}(\mathbf{5})$ and $\quad\left[\mathrm{Pd}_{6}\left(\mu-\mathrm{N}_{3}\right)_{2}(\mu-\mathrm{Pz})_{5}(\mu-\mathrm{IPz})_{5}\right]_{\mathrm{n}}$ \{pyrazolate $\left(\mathrm{Pz}^{-}\right)$, 4-methylpyrazolate $\left(\mathrm{mPz}^{-}\right)$, 3,5-dimethylpyrazolate $\quad\left(\mathrm{dmPz}^{-}\right), \quad 4$ iodopyrazolate $\left.\left(\mathrm{IPz}^{-}\right)\right\}$have been described in this work. The results showed that all thermal decompositions initiate with the release of organic and inorganic ligands, together with uptake of $\mathrm{O}_{2}$, leading to the formation of a mixture of $\mathrm{Pd}^{0}$ and PdO. TG studies showed that the introduction of substituted pyrazolato groups in the composition of the coordination polymers affect significantly their thermal stability. Taking into account the initial decomposition temperatures, the following thermal stability sequence could be established:

i) Compounds $\left[\operatorname{Pd}_{3}\left(\mu-\mathrm{N}_{3}\right)(\mu-\mathrm{L})_{5}\right]_{\mathrm{n}}: \mathrm{L}=\mathrm{IPz} \approx$ $\mathrm{mPz}>\mathrm{Pz}$

ii) Compounds $\left[\mathrm{Pd}_{6}\left(\mu-\mathrm{N}_{3}\right)_{2}(\mu-\mathrm{Pz})_{5}(\mu-\mathrm{L})_{5}\right]_{\mathrm{n}}: \mathrm{L}$ $=\mathrm{mPz}>\mathrm{IPz}>\mathrm{dmPz}$

These finding may indicate that coordination of presence of substituents at the 4 position exerts an extra effect on the thermal stability of compounds 1-6 probably due to packing effects. The introduction of an iodo or methyl group in position 4 of the ring pyrazolate increases the thermal stability of the polynuclear of formula $\left[\operatorname{Pd}_{3}\left(\mu-\mathrm{N}_{3}\right)(\mu-\mathrm{L})_{5}\right]_{\mathrm{n}}$. In the case of mixed polynuclear complexes $\left[\mathrm{Pd}_{6}\left(\mu-\mathrm{N}_{3}\right)_{2}(\mu-\mathrm{Pz})_{5}(\mu-\mathrm{L})_{5}\right]_{\mathrm{n}}$ is evident that the presence of pyrazolate substituted at the 3 and $5(\mathrm{~L}=\mathrm{dmPz})$ positions significantly increases 
the repulsive interactions along the polymer chain, resulting in a decrease in thermal stability. In this sense, compound $\mathbf{5}$ represents a good candidate to be further investigated as a precursor for the photolithography of Pd films due to its low thermal stability and good solubility in chloroform.

\section{Acknowledgements}

This work was sponsored by grants from FAPESP (proc. 2012/15486-3 and 2016/17711-5), CNPq (proc. 422105/2016-3) and CAPES.

\section{References}

[1] Chakrabarty, R., Mukherjee, P. S., Stang, P. J. (2011). Supramolecular coordination: self-assembly of finite two-and threedimensional ensembles. Chemical Reviews, 111(11), 6810-8.

[2] Chow, C-F., Fujii, S., Lehn, J-M. (2007). Metallodynamers: Neutral dynamic mettalosupramolecular polymers displaying transformation of mechanical and optical properties on constitutional Exchange. Angewandte Chemie, 46(26), 5007-10.

[3] Xu, W., Wang, J-G., Yu, M., Laegsgaard, E., Stensgaard, I., Linderoth, T. R., Hammer, B., Wang, C., Besenbacher, F. (2010). Guanine- and potassium- based two-dimensional coordination network selfassembled on $\mathrm{Au}(\mathrm{III})$. Journal of the American Chemical Society, 132(45), 15927-9.

[4] Dul, M-C., Pardo, E., Lescouëzec, R., Journaux, Y., Ferrando-Soria, J., RuizGarcía, R., Cano, J., Julve, M., Lloret, F., Cangussu, D., Pereira, C. L. M., Stumpf, H. O., Pasán, J., Ruiz-Pérez, C. (2010).
Supramolecular coordination chemistry of aromatic polyoxalamide ligands: A metallosupramolecular approach toward functional magnetic materials. Coordination Chemistry Reviews, 254 (1920), 2281-96.

[5] Pardo, E., Ruiz-García, R., Cano, J., Ottenwaelder, X., Lescouëzer, R., Journaux, Y., Lloret, F., Julve, M. (2008). Ligand design for multidimensional magnetic materials: a metallosupramolecular perspective. Dalton Transactions, 7(21), 2780-5.

[6] Han, F. S., Higuchi, M., Kurth, D. G. (2008). Metallosupramolecular polyelectrolytes self-assembled from various pyridine ring-substituted bisterpyridines and metal ions: photophysical, electrochemical, and electrochromic properties. Journal of American Chemical Society, 130(6), 207381.

[7] McMorran, D. A., Steel, P. J. (2002). New U-shaped components for metallosupramolecular assemblies: synthesis and coordination chemistry of 2,6-bis(3-pyridyloxy)pyrazine. Journal Supramolecular Chemistry, 14(1), 79-85.

[8] Hawes, C. S., Batten, S. R., Turner, D. R. (2014). Self-assembly of discrete and polymeric metallosupramolecular architectures from cyclen-derived ligands. CrystEngComm, 16(18), 3737-48.

[9] Steel, P. J., Fitchett, C. M. (2008). Metallosupramolecularsilver(I) assemblies based on pyrazine and related ligands. Coordination Chemistry Reviews, 252(8), 990-1006.

[10] Netto, A. V. G., Frem, R. C. G., Mauro, A. E., Crespi, M. S., Zorel, H. E. Jr. (2007). Synthesis, spectral and thermal studies on pyrazolate-bridged palladium(II) 
coordination polymers. Journal of Thermal Analysis and Calorimetry, 87(3), 789-92.

[11] Netto, A. V. G., Frem, R. C. G., Mauro, A. E. (2008). A química supramolecular de complexos pirazólicos. Química Nova, 31(5), 1208-17.

[12] Pérez, J., Riera, L. (2009). Pyrazole complexes and supramolecular chemistry. European Journal of Inorganic Chemistry, 2009(33), 4913-25.

[13] Zhang, J-P., Zhang, Y-B., Lin, J-B., Chen, X-M. (2012). Metal azolate frameworks: from crystal engineering to functional materials. Chemical Reviews, 112(2), 100133.

[14] Ardizzoia, G. A., Angaroni, M. A., La Monica, G., Cariati, F., Moret. M, Masciocchi, N. (1991). Reaction of dioxygen with $[\mathrm{Cu}(\mathrm{dmpz})]_{\mathrm{n}}(\mathrm{Hdmpz}=3,5-$ dimethylpyrazole). Crystal structure, reactivity, and catalytic properties of $\left[\mathrm{Cu}_{8}(\mathrm{dmpz})_{8}(\mathrm{OH})_{8}\right]$. Inorganic Chemistry, 30(23), 4347-53.

[15] Mezei, G., Baran, P., Raptis, R. G. (2004). Anion encapsulation by neutral supramolecular assemblies of cyclic $\mathrm{Cu}^{\text {II }}$ complexes: a series of five polymerization isomers, $\left[\left\{c i s-\mathrm{Cu}^{\mathrm{II}}(\mu-\mathrm{OH})(\mu-\mathrm{pz})\right\}_{\mathrm{n}}\right], \mathrm{n}=6$, 8, 9, 12 and 14. Angewandte Chemie, 43(5), 574-7.

[16] Netto, A. V. G., Frem, R. C. G., Mauro, A. E. (2005). Low-weight coordination polymers derived from the self-assembly reactions of $\mathrm{Pd}(\mathrm{II})$ pyrazolyl compounds and azide ion. Polyhedron, 24(9), 1086-92.

[17] Netto, A. V. G., Frem, R. C. G., Mauro, A. E. (2002). Synthesis and spectroscopic characterization of a novel coordination polymer of palladium(II) with pyrazole and azido ligands. Molecular Crystals and Liquid Crystals, 374(1), 255-60.
[18] Blair, S. L., Hutchins, J., Hilld, R. H., Bickley, G. (1994). Solid-state photochemistry of platinum(II) methylazide complexes as thin films on $\mathrm{Si}$ (111) surfaces: photolithography of platinum films. Journal of Materials Science, 29(8), 2143-6.

[19] Barra, C. V., Rocha, F. V., Netto, A. V. G., Shimura, B., Frem, R. C. G., Mauro, A. E., Carlos, I. Z., Ananias, S. R., Quilles, M. B. (2011). New palladium(II) complexes with pyrazoles ligands. Part I. Synthesis, spectral and thermal studies, and antitumor evaluation. Journal of Thermal Analysis and Calorimetry, 106(2), 489-94.

[20] Rocha, F. V., Barra, C. V., Netto, A. V. G., Mauro, A. E., Carlos, I. Z., Frem, R. C. G., Ananias, S. R., Quilles, M. B., Stevanato, A., da Rocha, M. C. (2010). 3,5Dimethyl-1-thiocarbamoylpyrazole and its Pd(II) complexes: synthesis, spectral studies and antitumor activity. European Journal Medicinal Chemistry, 45(5), 1698 702.

[21] de Souza, R. A., Stevanato, A., Treu-Filho, O., Netto, A. V. G., Mauro, A. E., Castellano, E. E., Carlos, I. Z., Pavan, F. R., Leite, C. Q. F. (2010). Antimycobacterial and antitumor activities of Palladium(II) complexes containing isonicotinamide (isn): X-ray structure of trans$\left[\mathrm{Pd}\left(\mathrm{N}_{3}\right)_{2}(\mathrm{isn})_{2}\right]$. European Journal of Medicinal Chemistry, 45(11), 4863-8.

[22] Barra, C. V., Rocha, F. V., Netto, A. V. G., Frem, R. C. G., Mauro, A. E., Carlos, I. Z., Ananias, S. R., Quilles, M. B. (2011). New palladium(II) complexes with pyrazoles ligands. Part II. Synthesis, spectral and thermal studies, and antitumor evaluation. Journal of Thermal Analysis and Calorimetry, 106(2), 483-8.

[23] Moro, A. C., Urbaczek, A. C., De Almeida, E. T., Pavan, F. R., Leite, C. Q. F., Netto, A. V. G., Mauro, A. E. (2012). 
Binuclear cyclopalladated compounds with antitubercular activity: synthesis and characterization of $\left[\left\{\mathrm{Pd}\left(\mathrm{C}^{2}, \mathrm{Ndmba}\right)(\mathrm{X})\right\}_{2}(\mu\right.$-bpp $\left.)\right](\mathrm{X}=\mathrm{Cl}, \mathrm{Br}$, $\mathrm{NCO}, \mathrm{N}_{3}$; bpp = 1,3-bis(4-pyridyl)propane). Journal of Coordination Chemistry, 65, 1434-42.

[24] Ferreira, J. G., Stevanato, A., Santana, A. M., Mauro, A. E., Netto, A. V. G., Frem, R. C. G., Pavan, F. R., Leite, C. Q. F., Santos, R. H. A. (2012). Structure and antimycobacterial activity of the novel organometallic [Pd(C-bzan $)(\mathrm{SCN})(\mathrm{dppp})]$ compound. Inorganic Chemistry Communications, 23, 63-6.

[25] Barra, C. V., Rocha, F. V., Gautier, A., Morel, L., Quilles, M. B., Carlos, I. Z., Treu-Filho, O., Frem, R. C. G., Mauro, A. E, Netto, A. V. G. (2013). Synthesis, cytotoxic activity and DNA interaction of Pd(II) complexes bearing N'-methyl-3,5dimethyl-1-thiocarbamoylpyrazole.

Polyhedron, 65, 214-20.

[26] Silva, C. da, Ferreira, J. G., Mauro, A. E., Frem, R. C. G, Santos, R. H. A., Da Silva, P. B., Pavan, F. R., Marino, L. B., Leite, C. Q. F., Netto, A. V. G. (2014). Synthesis and antimycobacterial activity of new pyrazolate-bridged dinuclear complexes of the type $\left[\mathrm{Pd}(\mu-\mathrm{L})\left(\mathrm{N}_{3}\right)\left(\mathrm{PPh}_{3}\right)\right]_{2} \quad\left(\mathrm{PPh}_{3}=\right.$ triphenylphosphine; $\mathrm{L}=$ pyrazolates). Inorganic Chemisrty Communications, 48, $153-5$.

[27] Rocha, F. V., Barra, C. V., Mauro, A. E., Carlos, I. Z., Nauton, L., El Ghozzi, M., Gautier, A., Morel, L., Netto, A. V. G. (2013). Synthesis, characterization, X-ray structure, DNA cleavage, and cytotoxic activities of palladium(II) complexes of 4phenyl-3-thiosemicarbazide and triphenylphosphane. European Journal Inorganic Chemisrty, 2013(25), 4499-505.

[28] Silva, C., Ribeiro, L. B., Furuno, C. C., Cunha, G. A. da, Souza, R. F. F., Netto, A. V. G., Mauro, A. E., Frem, R. C. G., Fernandes, J. A., Almeida Paz, F. A., Marino, L. B., Pavan, F. R., Leite, C. Q. F. (2015) Pyrazolyl Pd(II) complexes containing triphenylphosphine: Synthesis and antimycobacterial activity. Polyhedron, $100,10-6$.

[29] Bego, A. M., Frem, R. C. G., Netto, A. V. G., Mauro, A. E., Ananias, S. R., Carlos, I. Z., da Rocha, M. C. (2009). Immunomodulatory effects of palladium(II) complexes of 1,2,4-triazole on murine peritoneal macrophage. Journal of the Brazilian Chemical Society, 20(3), 437-40.

[30] International Center of Diffraction Data. Powder diffraction file:release. New Square, 1996. PDF n. 41-1107.

[31] International Center of Diffraction Data. Powder diffraction file:release. New Square, 1999. PDF n. 05-0681.

[32] Greenwood NN, Earnshaw A. Chemistry of the Elements. 2nd ed. ButterworthHeinemann; 1997. 